\title{
Physical Experiments on the Deformation of Strata with Different Properties Induced by
} Underground Mining

\author{
Haifeng $\mathrm{Hu}^{1 *}$, Xugang Lian ${ }^{1}$ and $\mathrm{Yu} \mathrm{Li}^{2}$ \\ College of Mining Engineering, Taiyuan University of Technology, Taiyuan 030024, China \\ ${ }^{2}$ Western Australian School of Mines, Curtin University, Kalgoorlie 6430, Australia
}

Received 28 December 2015; Accepted 10 March 2016

\begin{abstract}
Underground mining can cause ground and strata movements, which in turn cause damage to houses and the landscape. The different characteristics and properties of the strata encountered during mining can also result in corresponding deformation. In order to study the deformation and damage rules of strata which are composed of unconsolidated soil and bedrock induced by underground coal mining, a physical model that employs material sand, lime, and gypsum with water was utilized firstly to simulate strata and ground movements. Then overlying strata with different properties were created according to the corresponding ratio of the mixed material, physical models under two conditions (i.e., thick soil layer and thin bedrock, and thin soil layer and thick bedrock) were set up. Lastly underground coal extraction was conducted using the proposed models. Results show that the proportion of unconsolidated soil layer in the overlying strata is the key factor that determines the significant differences in the movement of strata under the two special conditions. When the ratio of the soil layer is large, the unconsolidated soil layer is loaded on the bedrock; the bedrock is thus forced to move down, and the compression rate of the broken strata is increased. The soil layer follows the bedrock as an integral movement to subsidence. When the ratio of the soil layer is small, the load on the strata is small, but the structural function of the strata is obvious and the fraction degree in the strata is developed. The obtained results in this study can be applied to support mine planning in the aspect of ground damage evaluation.
\end{abstract}

Keywords: Underground coal mining, Ratio of unconsolidated soil layer to bedrock, Strata deformation

\section{Introduction}

Strata deformation and movement caused by underground mining are highly complicated and tend to be concealed; thus, studying and understanding the displacement of strata induced by underground mining are difficult. However, a physical model experiment can easily simulate the entire deformation process, including the movement and caving of strata; hence, it is one of the best methods to study rock movement during mining. Besides, the overlying strata of a number of mining areas in China consist of bedrock and an unconsolidated soil layer. Bedrock and soil layers have different physical and mechanical properties in the underground mining process, and their deformation and movement are different. Under certain conditions, the bedrock and soil layer interact with each other. Therefore, it is of great importance to explore the influence of different ratios of the unconsolidated soil layer to bedrock on overlying strata movement.

\section{State of the Art}

Physical model is a general method for the study of strata movement and deformation. The thick unconsolidated soil layer is special and experiences a different movement. This characteristic has been an active research avenue. Zhou [1]

\footnotetext{
*E-mail address: tyhhf65@163.com

ISSN: 1791-2377 @ 2016 Eastern Macedonia and Thrace Institute of Technology.

All rights reserved.
}

studied the conditions of the Huainan coal mining area in China by combining physical simulation, theoretical analysis, and experimental data to study the subsidence mechanism induced by underground mining of a thick unconsolidated soil layer and established a predictive model. Ren [2] conducted a physical simulation test on an underground coal mine and analyzed the deformation and damage on the ground and wall rock during the mining process. Nakajima [3] conducted theoretical and experimental comparisons of the physical characteristics of the thick, hard rock that lies above the working face. The results showed that the minimum stable face length depends on the thickness of the hard rock. Zhang [4] explored the mechanism of surface subsidence caused by compaction of an unconsolidated layer and suggested that when the loose layer is thick, compaction of a water-bearing unconsolidated layer is inevitable; deformation of the soil body leads to additional stress and release of pore water, which result in consolidation. Liu [5] conducted physical simulations to study the movement of hard overlying strata induced by mining a shallow coal seam. The simulation results obtained using the "two hard" conditions showed that a cascading effect causes roof failure because of the extensive weight during pillar mining of a shallow seam, i.e., overlying strata caving over a large area occurs from the roof to the unconsolidated soil layer. Martin [6] studied the influence of the natural (or artificially induced) structure of a geomaterial on its compression behavior. The proposed compression model was utilized to simulate the behavior of various structured geo-materials, such as clay, sand, calcareous soils, clay-shale, soft rock, unsaturated soils, and soils artificially treated by adding chemical agents or mechanical reinforcement. The model 
was evaluated based on these simulations. Yong-Seok [7] studied the effect of nonlinear soil behavior on the inelastic seismic response of a structure, and the results clearly illustrated the importance of the nonlinear soil behavior. Shi [8] applied key stratum theory, established a mechanical model that can reflect the basic features of a rock stratum, and investigated the form and conditions of the fractures on main roofs. Gao [9] studied ground movement induced by underground wide strip mining. Ground deformation can be controlled to a certain degree if the widths of the strip mining and protective coal pillars are reasonable. Zheng [10] studied the dynamic subsidence principles of overloaded strata during underground coal mining by performing a test using similar materials. Ibrahim [11] studied the dynamic prediction model of ground subsidence caused by underground coal mining. The Knothe model and Geographic Information System were utilized in the model, and the $3 \mathrm{D}$ dynamic movement during underground mining was simulated effectively and efficiently based on the principle of fully mechanized backfilling and coal mining technology and combined with the Xingtai Coal Mine conditions. The goaf was backfilled with a solid material to a compact structure, and the strata behavior was desirable (the actual maximum vertical stress of the backfill body was 5.5 $\mathrm{MPa}$ ). Backfilling the body controlled the movement of overburden within a certain range, and no collapses occurred in the major areas in the overlying strata upon the backfilled goaf [12]. The block cave mining mechanism and associated subsidence are two of the most challenging engineering problems in rock mining. Fracture initiation, propagation and coalescence, breaking of the intact rock bridge, and evolution of a pressure-balancing arch in the stressed strata are represented visually during the entire caving process. Based on numerical results, the surface effects of block caving, such as subsidence profiles, break angles, fracture initiation angles, and subsidence angles at different initial caving depths, are illustrated in [13]. Fully mechanized backfilling mining technology with waste, fly ash, loess, etc., provides the advantages of safety and high efficiency during the extraction of coal under buildings, railways, and water bodies. Engineering application has confirmed that strata movement control in fully mechanized backfilling mining is highly effective and that the surface buildings and facilities are not severely affected [14]. The deformation characteristics of subsidence and movement induced by mining under thin bedrocks and thick unconsolidated layers have been investigated through field measurement and with the prediction method of artificial neural networks (ANNs). A quantitative prediction methods have been created for mining subsidence under thin bedrocks and thick unconsolidated layers through ANN. The improved neural network was utilized to model and predict mining subsidence in [15]. Haifeng $\mathrm{Hu}$ and Xugang Lian [16] studied the prediction model of ground damage degree under two special geological conditions: (1) thick unconsolidated soil layer and thin bedrock and (2) thin soil layer and thick bedrock. The rules for ground movement and deformation at different soil layer to bedrock ratios were obtained. Based on these rules, a prediction model of modified parameter of the influence function was proposed. This model is suitable for different values of unconsolidated soil layer thickness. The prediction results were verified with two sets of typical field data.

Physical experiments that employ similar materials are based on similarity theory, in which physical models are constructed using similar materials, such as sand, lime, and gypsum with water, whose physical properties are similar to those determined in field underground mining conditions. The experiments utilize artificial materials, and the physical properties are similar to those of the prototype. The geometric, kinematic, and dynamic similarities are constant; the similarity index is determined with similarity criteria, and the prototype is built at a certain model ratio.

Many studies on mining subsidence have been conducted. However, the roles of different strata components in underground mining remains unclear. What is the role of the soil layer in the strata, and what is the role of the bedrock in the strata? To answer these questions, a physical model was utilized in this study. Two typical ratios of the unconsolidated soil layer to bedrock were tested by utilizing a similar material model experiment. For the first ratio, (thick soil layer to thin bedrock), $\mathrm{Hs} / \mathrm{Hr}$ is large. For the second ratio, (thin soil layer to thick bedrock) $\mathrm{Hs} / \mathrm{Hr}$ is small. $\mathrm{Hs}$ is the thickness of the soil layer, and $\mathrm{Hr}$ is the thickness of the bedrock.

The remainder of this paper is organized as follows. Section 3 presents two physical experiments conducted under conditions of thick soil layer and thin bedrock, and thin soil layer and thick bedrock. Section 4 analyses and discusses the results of the physical experiments. The conclusions are summarized in Section 5.

\section{Methodology}

\subsection{Study area}

Two typical strata conditions are shown in Fig. 1. A project was conducted in southern Shanxi Province of China. The damage degree of ground induced by underground coal mining is serious, which is shown in Fig. 1 (a). The depth of the coal seam is $206.11 \mathrm{~m}$, including the bedrock $(19.9 \mathrm{~m})$ and soil layer $(186.21 \mathrm{~m})$. The width of the mining panel is $128 \mathrm{~m}$, the length is $164 \mathrm{~m}$, and the mining height is $6.6 \mathrm{~m}$. Another project was conducted in northern Shanxi Province. The damage degree of ground induced by underground coal mining is mild, as shown in Fig. 1 (b). The depth of the coal seam is $600 \mathrm{~m}$, including the bedrock $(560 \mathrm{~m})$ and soil layer (40 m). The width of the mining panel is $200 \mathrm{~m}$, the length is $710 \mathrm{~m}$, and the mining height is $10 \mathrm{~m}$.

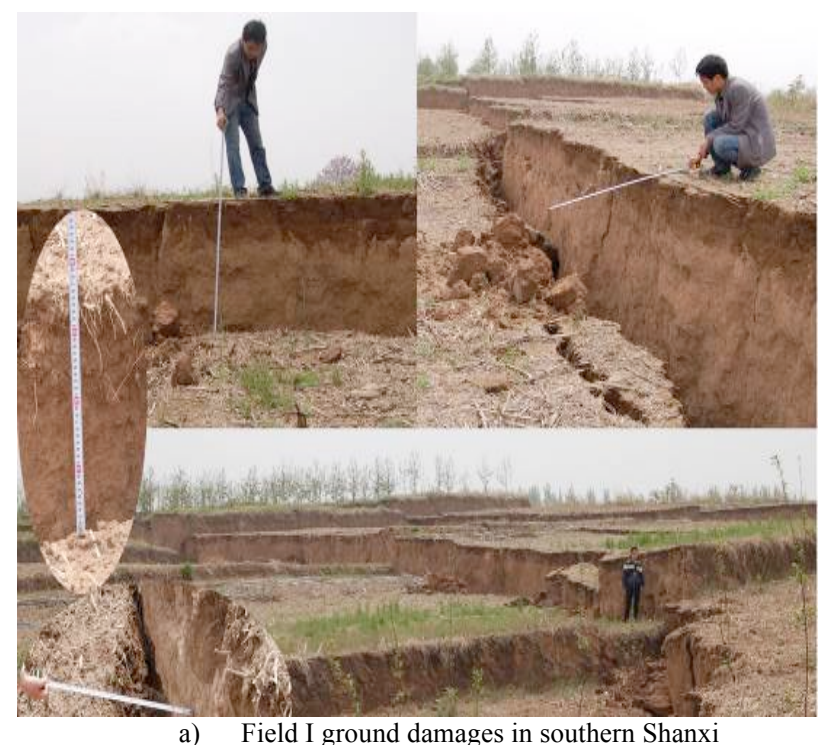

a) Field I ground damages in southern Shanxi 


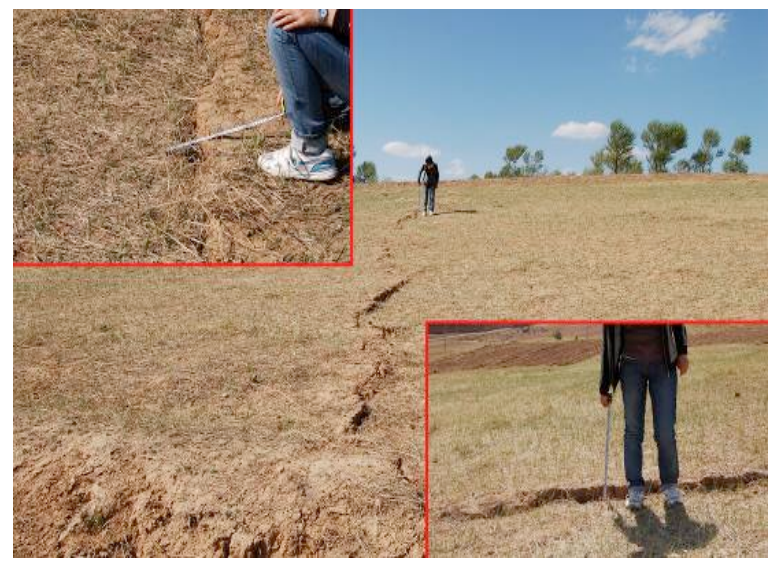

b). Field II ground damages in northern Shanxi Fig. 1. Ground damages caused by underground coal mining in Shanxi, China.
3.2 Case A: mining under condition of thick soil layer and thin bedrock

(1) Geology conditions of prototype panel 1101

The experiment utilized panel 1101 from the coal mine site in southern Shanxi, China, as the prototype. According to the strata drilling information, the thickness of the coal seam near the open-off cut of panel 1101 is approximately $6.5 \mathrm{~m}$, and the bedrock thickness is $19.9 \mathrm{~m}$. The main strata are sandy mudstone and siltstone, and the bedrock gradually thickens to the west. The overlying unconsolidated soil layer is approximately $186.21 \mathrm{~m}$ thick. The geology of this panel is typical for underground mining of an area under condition of thick soil layer and thin bedrock.

As shown in Table 1, soil permeability at ground level for panel 1101 is low, and the vertical permeability is less than $10^{-7} \mathrm{~cm} / \mathrm{s}$. Several soil layers are hard clay, whose liquidity index is below zero. This type of clay has a large bearing capacity; the structural properties and engineering geology conditions are good.

Table 1. Physical and mechanical properties of surface clay

\begin{tabular}{|c|c|c|c|c|c|c|c|c|c|}
\hline $\begin{array}{c}\text { Sample } \\
\text { No. }\end{array}$ & $\begin{array}{c}\text { Moisture } \\
\text { Content } \\
\%\end{array}$ & $\begin{array}{c}\text { Density } \\
\mathrm{g} / \mathrm{cm}^{3}\end{array}$ & $\begin{array}{c}\text { Plasticity } \\
\text { index }\end{array}$ & $\begin{array}{l}\text { Liquidity } \\
\text { index }\end{array}$ & $\begin{array}{c}\text { Compress } \\
\text { ibility } \\
\text { factor } \\
\mathrm{MPa}^{-1}\end{array}$ & $\begin{array}{c}\text { Modulus } \\
\text { of } \\
\text { compressi } \\
\text { on MPa }\end{array}$ & $\begin{array}{c}\text { Cohesion } \\
\text { kPa }\end{array}$ & $\begin{array}{c}\text { Angle of } \\
\text { internal } \\
\text { friction } \\
\left({ }^{\circ}\right)\end{array}$ & $\begin{array}{c}\text { Vertical } \\
\text { permeabil } \\
\text { ity } 10^{8} \\
\mathrm{~cm} / \mathrm{s}\end{array}$ \\
\hline 1 & 22.2 & 1.99 & 19.2 & 0.17 & 0.12 & 13.97 & 87.0 & 14.2 & 8.860 \\
\hline 2 & 19.1 & 2.08 & 17.5 & 0.06 & 0.09 & 17.31 & 102.0 & 10.8 & 36.500 \\
\hline 3 & 17.5 & 2.11 & 18.6 & -0.12 & 0.09 & 16.89 & 93.0 & 27.1 & 7.400 \\
\hline 4 & 21.7 & 2.01 & 20.3 & -0.12 & 0.07 & 23.61 & 183.0 & 31.1 & 1.980 \\
\hline 5 & 23.1 & 2.06 & 23.7 & -0.05 & 0.06 & 27.29 & & & 0.338 \\
\hline
\end{tabular}

(2) Physical model establishment

The model experiment platform must be very stable with sufficient stiffness. The size of the equipment is $1800 \mathrm{~mm} \times$ $160 \mathrm{~mm} \times 1400 \mathrm{~mm}$ (length $\times$ width $\times$ height). The simulated geology and mining conditions are based on panel 1101, and the model was simplified along the inclined direction of coal panel 1101. The simulated geology and mining conditions are as follows: inclined length of $164 \mathrm{~m}$, mining coal thickness of $6.6 \mathrm{~m}$, dip angle of $4^{\circ}$, average mining depth of $236 \mathrm{~m}$, and fully mechanized coal caving mining and caving method to manage the roof. The mechanical strength and density of the model can be determined according to these similarity constants. The scale of the prototype to the physical model was set to 250:1 based on the material ratio and amount shown in Tables 2 and 3. The model design is shown in Fig. 2. The model was built by proportioning the material, which was mixed with lime, sand and gypsum; the results are shown in Fig. 3.

Six observation lines (total of 175 points) were set to observe the movement of the model during the experiment. The top line was set near the ground and regarded as the observation of ground movement. The other five lines were set as the internal strata observations lines. The methods for setting the points and the results are shown in Figs. 2 and 3. The displacement of the observation points was obtained by the total stations, and surveying accuracy reached $0.1 \mathrm{~mm}$. Hence, for practical displacement, the accuracy can reach $0.1 \mathrm{~mm} \times 250=25 \mathrm{~mm}$.

\subsection{Case B: mining under condition of thin soil layer and} thick bedrock

(1) Geology conditions of prototype panel S2202

Coal panel S2202 is located in southern Shanxi, China. The thickness of the unconsolidated soil is approximately 40 $\mathrm{m}$, and the depth of the coal seam is approximately $500 \mathrm{~m}$ to $600 \mathrm{~m}$. The ground surface is flat. The main roof of S2202 is fine sandstone and siltstone with a thickness of $5 \mathrm{~m}$; the immediate roof is mudstone and sandy mudstone with a thickness of $1.66 \mathrm{~m}$ to $5.70 \mathrm{~m}$. The floor is siltstone with a thickness of $1.44 \mathrm{~m}$, and the main floor is fine sandstone with a thickness of $3.10 \mathrm{~m}$.

\section{(2) Physical model establishment}

The model platform dimensions are similar to those mentioned above. The simulated strata depth is approximately $600 \mathrm{~m}$, which includes a $40 \mathrm{~m}$ thick soil layer. The physical model setup and monitoring points are shown in Fig. 4.

\section{Result analysis and discussions}

\subsection{Results of case $A$}

The results for the ground observation line are shown in Fig. 5. After panel 1101 was extracted, the ground points experienced subsidence. The profile shows a flat part at A3A4, which illustrates that underground mining reached the critical stage. The maximum ground subsidence of the model 
is $5370 \mathrm{~mm}$, and the maximum ground horizontal movement is $1560 \mathrm{~mm}$. The corresponding field data are 5714 and 1462 $\mathrm{mm}$, respectively, so the experiment data effectively reproduce the field data. The experiment shows that under the condition of thin bedrock and thick unconsolidated solid layer mining, the subsidence coefficient is larger than normal, but the horizontal movement coefficient is smaller than normal. The subsidence curve changes rapidly above the coal rib; at the boundary subsidence basin $(10 \mathrm{~mm})$, convergence is slow, and the boundary expands substantially.

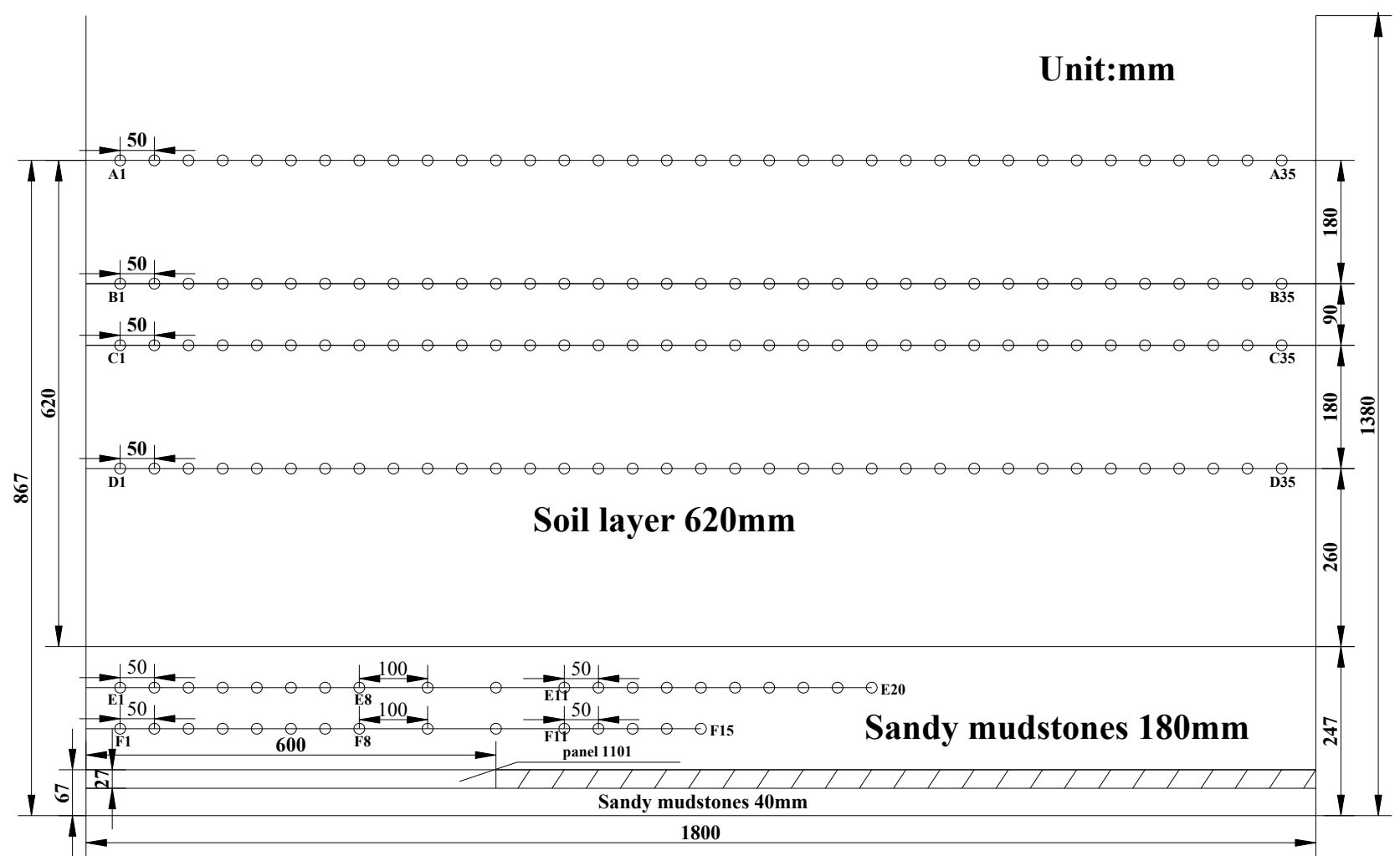

Fig. 2. Layout of measuring point in the experimental model.

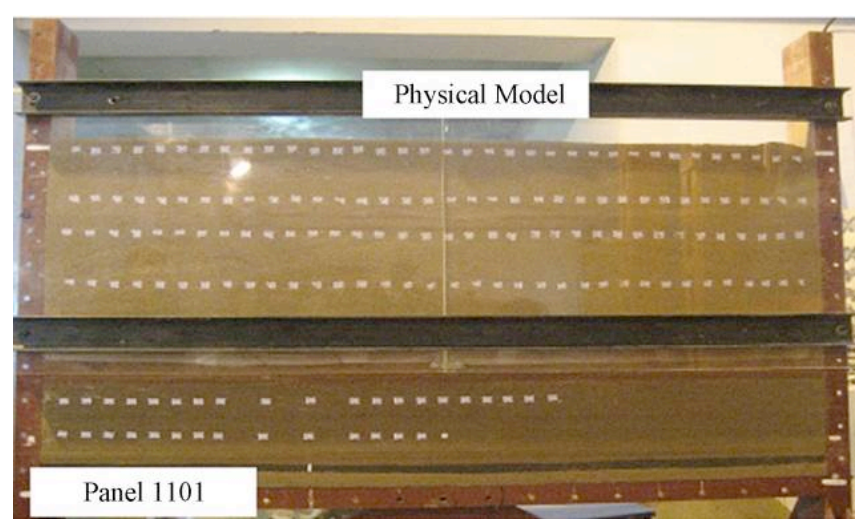

Fig. 3. Simulation setup for the model using a material similar to that of panel 1101

Table 2. Prototype and physical model of the occurrence and conditions andmechanical parameters of the comparison table

\begin{tabular}{|c|c|c|c|c|c|c|c|c|c|}
\hline \multirow[b]{2}{*}{ No. } & \multirow[b]{2}{*}{ Lithology } & \multicolumn{4}{|c|}{ Prototype } & \multicolumn{4}{|c|}{ Physical model } \\
\hline & & $\begin{array}{c}\text { Seam } \\
\text { thickness } \\
\text { m }\end{array}$ & $\begin{array}{c}\text { Depth } \\
\text { m }\end{array}$ & $\begin{array}{c}\text { Volum } \\
\text { e } \\
\text { weight } \\
\text { kN/m } \text { m }^{3}\end{array}$ & $\begin{array}{c}\text { Compressive } \\
\text { strength } \\
\mathrm{MPa}\end{array}$ & $\begin{array}{c}\text { Seam } \\
\text { thickness } \\
\text { mm }\end{array}$ & $\begin{array}{c}\text { Dept } \\
\text { h } \\
\text { mm }\end{array}$ & $\begin{array}{l}\text { Volume } \\
\text { weight } \\
\mathrm{kN} / \mathrm{m}^{3}\end{array}$ & $\begin{array}{c}\text { Compressive } \\
\text { strength } \\
\mathrm{MPa}\end{array}$ \\
\hline 1 & Soil layer & 155 & 155 & 20 & 1 & 620 & 620 & 12 & l \\
\hline 2 & Sandy mudstone & 45 & 200 & 25 & 45 & 180 & 800 & 15 & 0.108 \\
\hline 3 & Coal & 6.7 & 206.7 & 14 & 12 & 27 & 827 & 8.4 & 0.0288 \\
\hline 4 & Sandy mudstone & 10 & 216.7 & 22 & 40 & 40 & 867 & 13.2 & 0.096 \\
\hline
\end{tabular}


Table 3. Ratio of similar material simulation

\begin{tabular}{|c|c|c|c|c|c|c|c|c|c|c|}
\hline No. & Lithology & $\begin{array}{c}\text { Seam } \\
\text { thickness } \\
(\mathrm{cm})\end{array}$ & $\begin{array}{c}\text { Depth } \\
\text { (cm) }\end{array}$ & Ratio & $\begin{array}{c}\text { Sand } \\
(\mathrm{kg})\end{array}$ & $\begin{array}{c}\text { Lime } \\
\text { (kg) }\end{array}$ & $\begin{array}{l}\text { Gypsu } \\
\text { m (kg) }\end{array}$ & $\begin{array}{c}\text { Water } \\
\text { (kg) }\end{array}$ & $\begin{array}{c}\text { Total } \\
\text { weight } \\
\text { (kg) }\end{array}$ & Note \\
\hline 1 & Soil layer & 620 & 620 & $15: 0: 0$ & 263.23 & 0 & 0 & 0 & 263.23 & $\begin{array}{c}\text { Saw } \\
\text { powder } \\
13.2 \mathrm{~kg}\end{array}$ \\
\hline 2 & $\begin{array}{c}\text { Sandy } \\
\text { mudstones }\end{array}$ & 180 & 800 & $9: 8: 2$ & 103.68 & 9.22 & 2.30 & 8.06 & 115.20 & \multirow{3}{*}{$\begin{array}{l}\text { Water is } \\
7 \% \text { of the } \\
\text { total } \\
\text { weight }\end{array}$} \\
\hline 3 & Coal & 27 & 827 & $10: 7: 3$ & 11.31 & 0.79 & 0.34 & 0.87 & 12.44 & \\
\hline 4 & $\begin{array}{c}\text { Sandy } \\
\text { mudstones }\end{array}$ & 40 & 867 & $6: 5: 5$ & 15.80 & 1.32 & 1.32 & 1.29 & 18.43 & \\
\hline
\end{tabular}

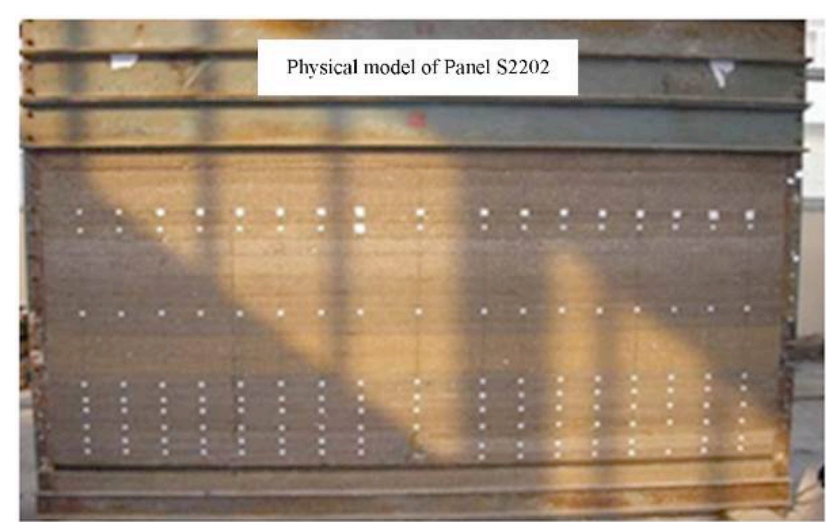

Fig. 4. Physical model setup and layout of monitoring points for Panel $\mathrm{S} 2202$

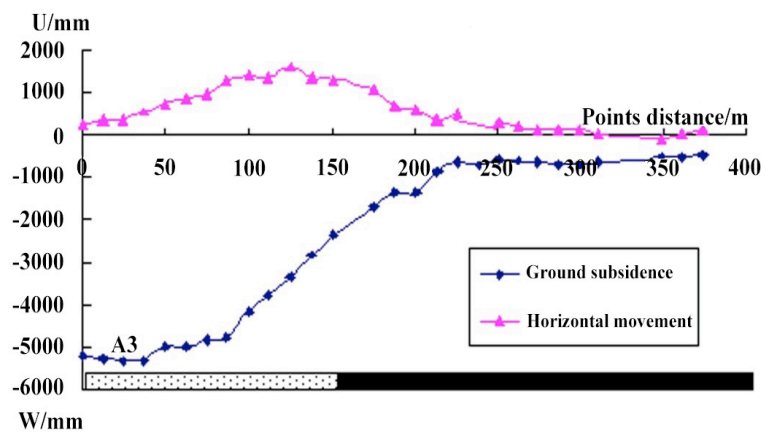

Fig. 5. Extracted ground movement curves.

The observation line $45 \mathrm{~m}$ above the coal seam after panel 1101 was extracted from the model is shown in Figure 6. The subsidence of E1 to E7 is uniform distributed, and the value is approximately $5650 \mathrm{~mm}$. Maximum subsidence of $6025 \mathrm{~mm}$ was observed at point E8. However, at point E9, the subsidence is small, and the subsidence of E9-E20 is minimal. Extraction caving in the strata migrates upward as a breaking angle. The results shown in Figs. 5 and 6 indicate that the subsidence of the internal strata is larger than that of the ground surface; however, the subsidence of the pillar is smaller than that of the ground.

Owing to the panel 1101 under the condition of thick unconsolidated soil layer and thin bedrock, the hard control strata layer (key stratum) does not exist. Hence, mining caving propagates toward the ground rapidly, surface subsidence is dramatic, and the ground subsidence coefficient and subsidence values are large, resulting in a high subsidence velocity. Ground movement and deformation are concentric to the underlying caving geometry.

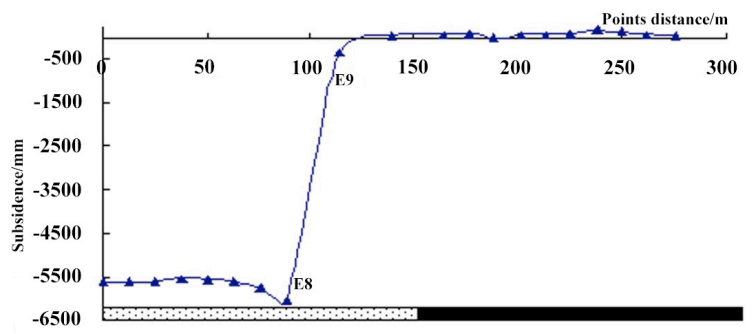

Fig. 6. Subsidence curve of bedrock $45 \mathrm{~m}$ above the coal seam after extraction

\subsection{Results of case B}

An open-off cut of coal seam in the model that was $6 \mathrm{~m}$ wide and $2.75 \mathrm{~m}$ high at a distance to the boundary of $16 \mathrm{~m}$ was made based on field data. Subsequently, additional cuts with $2.4 \mathrm{~m}$ width were made in the coal seam. With the advancement of the working face, the overlying rock gradually bent, as shown in Fig. 7A. When the face advanced to $28 \mathrm{~m}$, the mudstone and sandy mudstone above the coal caved, as shown in Fig. 7B. Thus, the caving step distance is $28 \mathrm{~m}$, and the thickness of roof caving is $2 \mathrm{~m}$. When the active face advanced to $40 \mathrm{~m}$, the immediate roof experienced a second caving; thus, the caving step is $8.8 \mathrm{~m}$, as shown in Fig. 7C. Based on the above results, the initial caving step distance is $28 \mathrm{~m}$, and the periodic caving step distance is approximately $8.8 \mathrm{~m}$.

Upon advancing to $44 \mathrm{~m}$, the main roof caved. The main roof caved at a distance of $44 \mathrm{~m}$; the height of the caving is 3 $\mathrm{m}$, and the length on the top of the caving zone is $38 \mathrm{~m}$. The shape of the main roof caving is an isosceles trapezoid with a caving angle of $63^{\circ}$, as shown in Fig. 7D.

Upon advancing to $62.4 \mathrm{~m}$, the bottom strata of the main roof broke and caused the main roof to experience periodic weighting. The step weighting distance is $18.4 \mathrm{~m}$, the height of the roof caving is $3 \mathrm{~m}$, and the caving angle is $61^{\circ}$, as shown in Fig. 7E. Upon advancing to $72 \mathrm{~m}$, the main roof experienced a second periodic weighting; the step weighting distance is $17.6 \mathrm{~m}$, and the caving angle is $65^{\circ}$. When the roof experienced weighting, the limestone with a thickness of $4.7 \mathrm{~m}$ on the top part of the main roof broke, formed a hinging joint rock beam, and caused the sandy mudstone and sandstone to break and subside, as shown in Fig. 7F.

Several conclusions can be obtained from this experiment. The distance of the initial caving step of the immediate roof is $28 \mathrm{~m}$, and the periodic caving step is 8.8 $\mathrm{m}$. The initial caving distance of the main roof is $44 \mathrm{~m}$, and the periodic caving step ranges between 17.6 and $18.4 \mathrm{~m}$ (averaging at $18 \mathrm{~m}$ ). When the working face advances, the bottom strata gradually break and subsidence gradually 
increases; when the maximum is reached, the newly formed basin moves in the direction of the advancing face. As the distance from the strata to coal increases, the subsidence

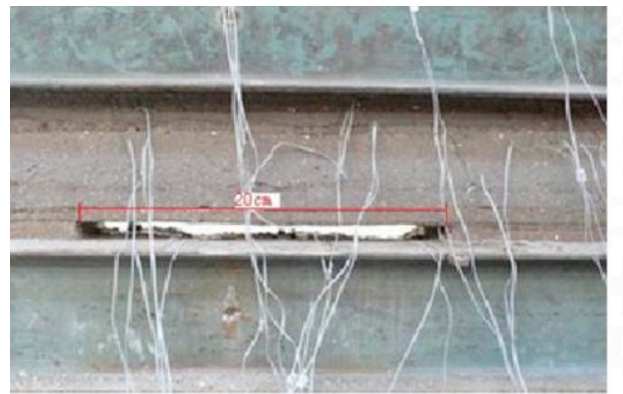

A) advancing $16 \mathrm{~m}$ (field)

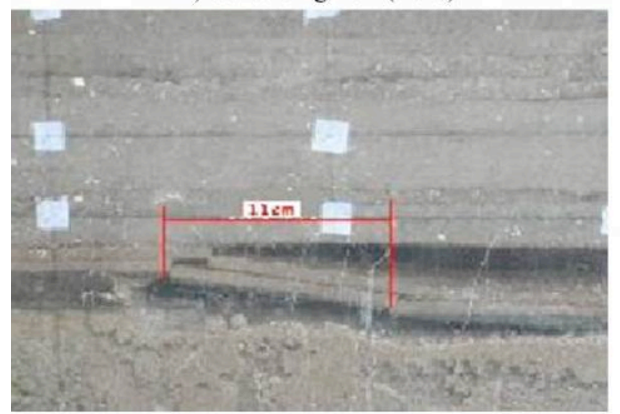

C) Second caving of first roof

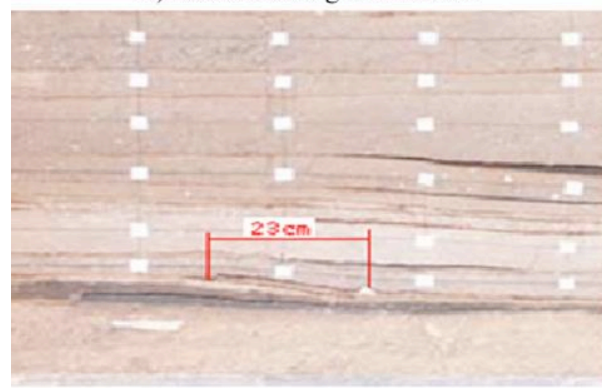

E) Periodic caving of main roof-1

Fig. 7. Strata damage and deformation simulation of panel S2202.

Under the condition of thick unconsolidated soil layer and thin bedrock, and fully mechanized caving mining, caving fracture zones developed and even reached the bedrock surface. The height of the caving zone rapidly increased because of the lack of hard control strata. Fractures, separation, and damage were observed in the fracture zone. Generally, the integrity and continuity of the bending zone are good, but because of the thin bedrock above the coal seam, the bending zone does not exist. The above information illustrates three typical zones of the main strata damage zone in underground mining. Qualitative rules for strata deformation related to mining were derived from the experiments. The test scheme was created based on the experimental equipment, so ground and strata movement and deformation in the field were lacking.

A significant difference exists between the movement mechanisms of bedrock and unconsolidated soil induced by underground mining. Mining or strata movement under the bedrock can cause the movement of the bedrock, but partial mining and partial internal compression from soil can cause the movement of unconsolidated soil. When the ratio of the soil layer to the bedrock is large, ground movement is large; however, the ground only slightly discontinuously deforms. The movement of internal bedrock is in the critical stage, and the rock compression rate is high. When the ratio of the soil layer to the bedrock is small, ground movement is small; value gradually decreases. The maximum height of the caving zone to coal is approximately $19.2 \mathrm{~m}$.

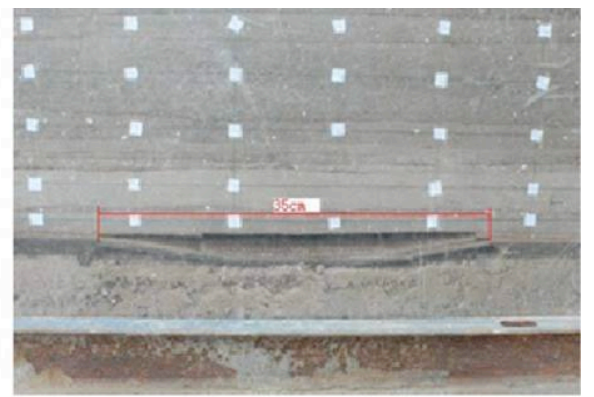

B) Initial caving of first roof

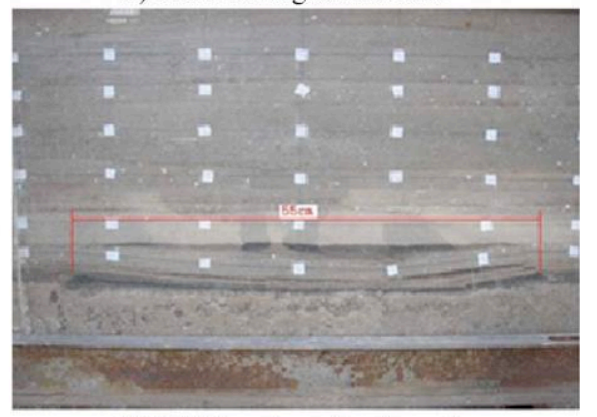

D) Initial caving of main roof

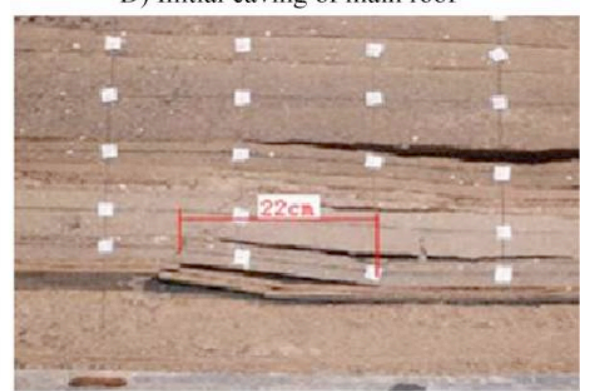

F) Periodic caving of main roof-2

however, the discontinuous deformation of the ground is pronounced in shallow mining conditions. The movement of internal bedrock is in the sub-critical stage, and the rock compression rate is low.

\section{Conclusions}

The movement of strata with different properties induced by underground coal mining was investigated, with special focus on the soil layer ratio in the strata. Physical experiments were conducted to model the movement of strata with different ratios of unconsolidated soil to bedrock. These experiments allowed for the determination of several rules of deformation of overlying strata of the coal seam.

The coupling relationship between the bedrock and an unconsolidated soil layer was revealed. Under the condition of a thick soil layer and a thin bedrock, the control layer (key stratum) is difficult to form in the bedrock to prevent the dramatic subsidence of the soil layer. As a load, the unconsolidated soil layer lies on the top of the bedrock and thus causes the integrated movement of the soil layer to follow the bedrock. Only when the bedrock is thick will it form a support structure and support the load from the unconsolidated soil layer. 
The conclusions obtained in the study can be applied to reveal the surface damage rules in coal mining area under condition of thick soil layer and provides technical support for mining subsidence prediction in mine planning.

\section{Acknowledge}

The study was supported by the National Natural Science Foundation of China (51574132 and 51504159) and the
Natural Science Foundation of Shanxi Province, China (2014011001-3).

\section{References}

1. Dawei Zhou, Kan Wu, Gong-Lin Cheng et al, "Mechanism of mining subsidence in coal mining area with thick alluvium soil in China". Arabian Journal of Geosciences, 8(4), 2014, pp. 1855-1867.

2. Weizhong Ren, Chengmai Guo, Ziqiang Peng et al, "Model experimental research on deformation and subsidence characteristics of ground and wall rock due to mining under thick overlying terrane". International Journal of Rock Mechanics and Mining Sciences, 47(4), 2010, pp.614-624.

3. Shigeo NAKAJIMA, "Basic Model for Surface Subsidence and Rock Strata Caving--Caving and subsidence of rock strata by wall type mining (1 st Report)". Shigen-to-Sozai, 115(3), 1999, pp.137-144.

4. Hongri Zhang, Guibin Zhang, Yuanyuan Sheng et al, "Mechanism and Prediction Research of the Surface Mining Subsidence of Thick Loose Layers in Mining Area". Applied Mechanics and Materials, 204208, 2012, pp.3488-3493.

5. Liu Chungui, "Similar simulation study on the movement behaviour of overlying strata in shallow seam mining in Majiliang Coal Mine". Journal of the China Coal Society, 2011, pp.7-11.

6. Martin D. Liu, John P. Carter and Chandra S. Desai, "Modeling Compression Behavior of Structured Geomaterials". International Journal of Geomechanics, 3(2), pp.191-204.

7. Yong-Seok Kim, Jose M. Roesset, "Effect of Nonlinear Soil Behavior on Inelastic Seismic Response of a Structure". International Journal of Geomechanics, 2004(2), pp.104-114.

8. Jianjun Shi, Runhua Wu, Tao Yong et al, "Research on the Simulation of the Roof Fracture about the Gob-Side Entry Retaining". Advanced Materials Research, 734-737, 2013, pp.624-627.

9. Baobin Gao, Lin Li, Huigui Li, "Experimental Study on Wide Strip Mining with Similar Simulation under Deep-Lying Seams". Applied Mechanics and Materials, 295-298, 2013, pp.3318-3322.
10. Ruyu Zheng, Kan Wu, Ru Li, "Study on Overburden's Destructive Rules Based on Similar Material Simulation".International Journal of Modern Education and Computer Science, 3(5), 2011, pp.54-60.

11. Ibrahim Djamaluddin, Yasuhiro Mitani and Hiro Ikemi, "GISBased Computational Method for Simulating the Components of 3D Dynamic Ground Subsidence during the Process of Undermining". International Journal of Geomechanics, 12(1), 2012, pp.43.

12. Zhang Qiang, Zhang Jixiong and Huang Yanli et al, "Backfilling technology and strata behaviors in fully mechanized coal mining working face". Mining Science and Technology, 22(2), 2012, pp.151157.

13. L. C. Li, C. A. Tang and X. D. Zhao et al, "Block caving-induced strata movement and associated surface subsidence: a numerical study based on a demonstration model". Bulletin of Engineering Geology and the Environment, 73(4), 2014, pp.1165-1182.

14. Jixiong Zhang, Nan Zhou and Yanli Huang et al, "Impact law of the bulk ratio of backfilling body to overlying strata movement in fully mechanized backfilling mining". Journal of Mining Science, 47(1), 2011, pp.73-84.

15. Weifeng Yang, Xiaohong Xia, "Prediction of mining subsidence under thin bedrocks and thick unconsolidated layers based on field measurement and artificial neural networks". Computers and Geosciences, 52, 2013, pp.199-203.

16. Haifeng Hu, Xugang Lian, "Subsidence rules of underground coal mines for different soil layer thickness: Lu'an Coal Base as an example". International Journal of Coal Science \& Technology, 2(3), 2015, pp.78185. 